\title{
Foreclosure on collateral under French and Vietnamese laws
}

\author{
Le Bich Thuy*
}

University of Economics and Law, VNU-HCM

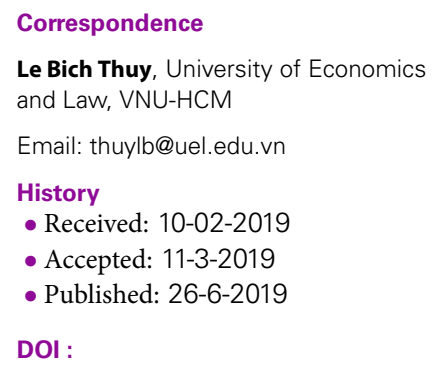

Le Bich Thuy, University of Economics and Law, VNU-HCM

Email: thuylb@uel.edu.vn

History

- Received: 10-02-2019

- Accepted: 11-3-2019

- Published: 26-6-2019

DOI :

https://doi.org/10.32508/stdjelm.v3i2.548

\section{Check for updates}

\section{Copyright}

(.) VNU-HCM Press. This is an openaccess article distributed under the terms of the Creative Commons Attribution 4.0 International license.

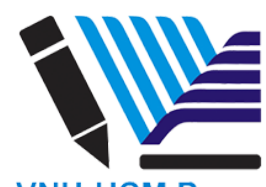

VNU-HCM Press

\begin{abstract}
In Vietnam, as a result of limited financial competence, it is quite normal for small and medium enterprises to acquire loans from credit institutions, mostly under pledge and mortgage agreements. With the purpose of fostering economic growth, it is, therefore, very important to help individuals and businesses gain access to credit and increase the credit availability for them. In order to do so, obviously the possibility of predicting the time and cost involved in the realization of their security rights should be clearly seen by creditors through clear and effective regulations on enforcement or particularly on the foreclosure of collateral. In fact, Vietnamese laws on secured transactions has recently been developed under the Civil Code 2015, adding two new security devices which are retention of title and retention of property. The new code also clearly distinguishing security devices which have the characteristic of personal rights and real rights as well as perfects the mechanism of effectiveness against third parties. The paper focuses on presenting the differences between the foreclosure o pledged and mortgaged property in French laws and in Vietnamese laws and suggests some modifications to Vietnamese relevant statutes to protect the rights of both debtors and creditors in pledge and mortgage transactions, learning from French practices. Recommendations include a more active role of the securing party in serurity right enforcement process under judicial supervision, the court's involvement in property value appraisal, an extra-judicial mechanism for creditors for collaterall repossession and a provision setting forth an obligation of the secured party to diligently and effectively exploit the secured property to earn maximum fruit and incomes and deduct such amount from the interest and original loan.
\end{abstract}

Key words: collateral, foreclosure, security right enforcement, retention of title

\section{INTRODUCTION}

Vietnamese Civil Code 2015, which is in effect since the first of January 2017, contains some innovations including the provisions concerning security for obligation performance. In particular, the Code added two new security devices which are retention of title and retention of property. The Code also clearly distinguishes security devices which have the chacteristics of personal rights and real rights as well as perfects the mechanism of effectiveness against third parties. At the same time, Civil Code 2015 regulates that registration of a security device is a right rather than an obligation. The approach taken by Vietnamese Civil Code 2005 was believed to majorly base on the 200 year-old French Civil Code and over-100-yearold Japanese Civil Code and hence Vietnamese body of secured transaction law was considered as antiquated, opaque and incomplete ${ }^{1}$. However, both provisions of 2005 Civil Code and provisions regulating secured transactions of the newly amended 2015

\footnotetext{
${ }^{1}$ See Xuan-Thao Nguyen and Bich Thao Nguyen . Transplanting Secured Transaction Law: Trapped in the Civil Code for Emerging Economy Countries. Robert H. McKinney School of Law. Legal Studies Research Paper.No. 2014-39,pp 23-25
}

Civil Code of Vietnam, in fact, has not inherited the best quintessence of French civil code.

In Vietnam, the financial competence of small and medium enterprises is relatively limited and a majority of businesses have to acquire the loan from credit institutions, mostly under a pledge and mortagage agreements.

Therefore, it is necessay that the credit availability should be encouraged for the sake of an economic growth in general. To allow the creditors the possibility of predicting the time and cost involved in the realization of their security rights, clear and effective regulations on enforcement or particularly on the foreclosure of collateral is significantly important, affecting both the availability and the cost of credit offered. The following paper focuses on the differences between French laws and Vietnamese laws in relation to the foreclosure on pledged and mortgaged property with the purpose of suggesting some modifications to Vietnamese relevant statutes to best protect the right of both debtors and creditors in pledge and mortgage transactions. 
THE CASES OF COLLATERAL FORECLOSURE

Pursuant to Vietnamese Civil Code 2015, there are three circumstances when collateral is foreclosed. It is when there is a failure in secured obligation performance or when parties have agreement about the case or when law provides the case that party with obligation has to perform its obligations before they become due. Other circumstances of collateral foreclosure depend on parties' specific agreement or law provision ${ }^{2}$. Meanwhile, French law security interest may be only enforced upon an occurrence of a payment default (either resulting from a non-payment of interest, fees or principal or following an acceleration of the secured facilities) ${ }^{3}$.

The regulations provided by Vietnam seems to be more flexible than those by French Civil Code and closer to international best practices ${ }^{4}$.

\section{METHODS OF COLLATERAL FORECLOSURE}

In Vietnam, concerning methods of foreclosing pledged or mortgaged property, two main ways are generally provided which are in accordance with parties' agreement and in accordance with the law. General provisions address foreclosure on both pledged and mortgaged property similarly. Looking at how legislators arrange the order of such methods in Article 303, it is noticeable that Vietnamese Civil Code 2015 put the priority on parties' agreement ${ }^{5}$ and only when parties do not have agreements in advance, the public auction or other methods provided by law are considered $^{6}$.

However, instead of letting parties freely choose kinds of agreement, law provisions relating to security transactions give guidance and suggestions to parties by explicitly and specifically presenting three methods which are the sale on auction, the sale by secured party and keeping the collateral as substitution for obligations. This, unfortunately, leads to some concerns.

\footnotetext{
${ }^{2}$ See Article 299, Vietnamese Civil Code 2015

${ }^{3}$ See Article 2346 French Civil Code

${ }^{4}$ See Article 9, Uniform Commercial Code

${ }^{5}$ See Point 1 and 2, Article 303, Vietnamese Civil Code 2015 on Methods of Foreclosure on Pledged or Mortgaged Property

Point 1 . The debtor and the secured party may agree on one of the following methods of foreclosure on pledged or mortgaged property:

a) Sale of the collateral on auction;

b) The secured party sells the collateral by itself;

c) The secured party keeps the collateral in substitution of the debtor's performance of obligation;

d) Other methods.

Point 2. In case there is no agreement on the method of foreclosure as provided in paragraph 1 of this Article, the collateral shall be auctioned, unless otherwise provided by law.

${ }^{6}$ See Point 2, Article 303, Vietnamese Civil Code 2015
}

Concern 1: the passive role of the party with obligation in the process of property foreclosure brings less benefit to both parties.

A first look at Article 303, Vietnamese Civil Code 2015 may give us an impression that parties to a security transaction are allowed to be very creative in negotiating and choosing the methods of foreclosing the secured property. Nevertheless, there is little tendency that people, especially lay people without much legal knowledge and with little practical experience, may think of any other solutions rather than strictly follow the options suggested by such provision. Consequently, the choice of methods may just limit to the ones provided by the law. In addition, currently, the latest draft Decree of Government on security transaction with the purpose of replacing Decree No. 163/2006/NĐ-CP of Government on security transaction also gives instruction on how the secured party may substitute the property or sell the property itself or conduct sale on auction but gives extremely general instruction on other methods ${ }^{7}$, implying the fact that other methods are not popular and that the party with obligation plays no role in the process of property foreclosure and is not expected to actively involve in such process .

Specifically, Article 60 of the latest draft Decree of Government on security transaction provides that "After 3 times of price decrease, if the secured property cannot be sold, the secured party is entitled to substitute the property for obligation performance with the last decreased price". In fact, because "the sole purpose of security rights is to secure repayment of the debt and brings no enrichment to the creditors" 8 and the foreclosure of collateral is not a business activity to help the secured party have profit, the secured party in general does not want to gain the ownership over the secured property, which will entail the requirement of spending more time and effort on a lot of issues such as transferring the title, selling the collateral to recover the loan. Moreover, if the secured party sells the property itself, it may want to sell the property as quickly as possible even with lower value as the actual value of the property or sell it with equal or even lower value than the loan to mitigate loss and recover the loan. Consequently, the possibility that the secured party returns the difference between the selling price (or the value) of the secured asset and the

\footnotetext{
${ }^{7}$ See Article 59, Article 60 and Article 61, latest draft Decree of Vietnamese government on security transaction

${ }^{8}$ See M Cabrillac \& C Mouly. Droit des suretes. 2004. Litec Lexis Nexis. No 535;
} 
value of the secured obligation as provided by the law ${ }^{9}$ seems hard to do. Furthermore, the sale on auction, without the total understanding and consent of the party with obligation, may also turn to a nightmare to all people involved.

In order to avoid the aforementioned issues, Vietnamese legislators can learn from their French counterparts.

Originally France only provided for a public sale under strict monitor and control of the court but the country now has left this issue as much as possible to the parties themselves and limited the court intervention to a minimum (but still required ) to simplify the distribution proceedings ${ }^{10}$. Once the debtor is in default, at the beginning, after the order to pay has been served on the debtor, there are two possibilities: an equitable procedure or an enforcement procedure. Both procedures are under the supervision of the Court to some extents. In an equitable procedure, the debtor is allowed to find a purchaser himself. In an enforcement procedure, the property will be auctioned. However, the recent reform in French civil code allows the parties to enter into agreement providing for enforcement outside the legal framework (eg. Private sale mandate to the party with obligation, to security holder or third party to sell ${ }^{11}$ ). Different from Vietnamese law-makers, French legislators emphazise the freedom of parties in making decision about the ways to foreclose the property pledged or mortaged by expecting the securing party to participate more actively in foreclosure process.

Pursuant to French Civil Code, pledge can be with or without property possession ${ }^{12}$ and in case of the payment default, the pledgor or mortgagor can sell the property itself or sell on action under the supervision of the court ${ }^{13}$. Additionally, as regulated by R22130 French Civil Procedure Code for Enforcement, the debtor has a duration of one month to sell the secured property itself from the date of court notice about the seizure of secured property for foreclosure. The sale of property is under the supervision of the court ${ }^{14}$ - This method is believed to bring about flexibility which is the main feature of the recent reform to the law of foreclosure proceedings in France. The mentioned method is considered to generally have the following advantages:

\footnotetext{
${ }^{9}$ See Point 3, Article 305 Vietnamese Civil Code 2015

${ }^{10}$ See Décret 27 July 2006 JO 29 july 2006 relatif aux procédures de saisie immobilière et de distribution du prix d'un immeuble (Decree $\mathrm{n}^{\circ}$ 2006-936 of July 27 th, 2006 relating to the procedures of foreclosure and distribution of the price of a building);

${ }^{11}$ See Article 2340-2344 French Civil Code

${ }^{12}$ See Article 2340-2344 French Civil Code

${ }^{13}$ See L322-1 French Civil Procedure Codes for Enforcement

${ }^{14}$ See R221-30 and R322-21 French Civil Procedure Codes for Enforcement
}

- Flexibility allows the debtor to actively find a purchaser himself: The debtor may submit a request for a voluntary sale before the service of summons to appear at the direction hearing or the debtor may submit such request at the direction hearing. The voluntary sale is always under the control of the judge who checks that the price offered for the foreclosed property is at the market price. Specifically, at the reminder hearing, the debtor informs the judge he/she has found a purchaser and gives the price offered by this purchaser. The judge checks that the price is at market value, and if so, the sale is allowed. A lot of indicators and statistics given by notaries will enable the judge to confirm whether the price is at market value. After the reminder hearing, the sale is closed by a deed drafted by a notary.

- Flexibility also means that the property may be sold at a better price while making the foreclosure process less traumatic for the debtor. Generally the debtor has the impression that he/she has a certain control over the procedure and sells the property without any pressure and is therefore more likely to quit the property quietly without aggressive opposition and further complications.

- Flexibility helps avoid the eviction proceedings in case the secured property is an accomodation: if a sale of the property by auction does not involve the debtor, the debtor could cause difficulties, which may lead to eviction proceedings being required and hence can take a long time and entails a lot of complications. For instance, in France the eviction proceedings is very timeconsuming and may take up to 2 years because the occupier has a lot of legal protection. For example: In the winter period (from November 1st to March $\left.15^{\text {th }}\right)$, no eviction from private property may take place. In addition, the claimant creditor has a duty (not prescribed by law, however customarily) to endeavour to find alternative accommodation for evicted persons. Then, the police will only help the bailiff in eviction proceedings after they have completed a social report on the potential evictee, which can be a long process. The eviction procedure can be complicated and take time, which is a good reason why the debtor should, be involved in the sale process. 
- Flexibility helps the creditor avoid becoming the owner of the foreclosed property. What the secured party wants is to recover the loan, not to become the owner of the secured party. Therefore, creditors may be less hesitant to grant a credit once they can ensure that there is higher possibility of loan recovery with the more active involvement of debtors in foreclore process.

\section{Concern 2: How to ensure the obligation} performance of the securing party once it has sold the secured property itself

A concern may rise with regard to the possibility that the debtor may sell the property but still refuses to perform the secured obligation. To avoid such circumstance, France provides that the sale of property by the debtor has to be conducted under the court's control with the form of "hypothèque judiciaire conservatoire". A "hypothèque judiciaire conservatoire" is not necessarily created by a court ruling but needs to be permitted by a judge. At the reminder hearing, the debtor informs the judge that a purchaser has been found and gives the price, a deed drafted by a notary is then inspected buy the judge and the purchaser will deposit the full sum into an escrow account. In such a way the court can control the money that the debtor gets from the sale of secured property and prevent the second default of the debtor ${ }^{15}$.

From the experience of France, a country with long history, in case of obligation default, it is advisable that Vietnamese Civil Code and its other relevant legislations should regulate in the way that can encourage debtor to act more actively in foreclosure process by explicitly introducing a method where the debtor is allowed to sell the property itself under different levels of judicial control.

Concern 3: How to value the price of the secured property in case the secured party keeps the collateral in substitution for the debtor's performance of obligation

There is a similarity between Vietnam and France when both jurisdictions have provisions regulating that the creditor can take the secured property and have its title to substitute for the obligation performance in case of payment defaults ${ }^{16}$. The discrepancy is how the secured property is valued. In Vietnam, pursuant to Article 306 Civil Code 2015, Article 18 Decree No. 11/2012/ND-CP amending a number

\footnotetext{
${ }^{15}$ See L511-1 French Civil Procedure Codes for Enforcement

${ }^{16}$ See Point 1 and 2, Article 305 Vietnamese Civil Code 2015 and Art 2365 and 2459, French Civil Code
}

of articles of Decree No. 163/2006/ND-CP (Decree 163), on implementation of relevant provisions of the Civil Code on secured transactions, Article 64b Decree No. 163/2006/ND-CP of Government on security transaction and the latest draft Decree of Government on security transaction, parties may agree on the value of the secured property or the value can be appraised by an appraisal organization. While the secured party is normally a credit institution with the advantage of information and senior position of lender, the securing party is often an individual or enterprise with a weaker position of the debtor whose voice may not be as strong and influencing, resulting in a possibility that the value of the collateral may not be appraised as high as its actual value should be if parties choose to agree on the value of the secured property. Hence, the possible disadvantage may happen to the securing party in case parties agree on the value of the property without any intervention from an independent third party or without any court intervention.

On the contrary, the French legislation in the 2006 reform has stipulated that it may be agreed in the mortgage deed that the creditor is to become the owner of the mortgaged property (pacte commissoire) ${ }^{17}$ and that the parties may agree at any time that the pledge acquires ownership over the assets as a result of the default of the pledger. At the same time, to avoid the exploitation over debtor, French law also provides that if the assets are not listed and do not have a market price, in all cases, it is necessary that an expert designated by the parties or by the court should be present to determine their value at the time of title transfering $^{18}$. French Code Civil prohibits every clauses that allow the pledgee to appropriate the collateral on default of the debtor with out sale or test of its value $\mathrm{e}^{19}$. In addition, if the property is the main residence of the debtor, the creditor cannot keep the property to substitute for the obligation performance ${ }^{20}$.

From the above analyzed points, to better protect the rights of debtor, it is suggested that Vietnamese legislators should amend Point 1 and Point 2, Article 305 Civil Code 2015 as follows: if parties have agreement about keeping of the collateral in substitution for the debtor's performance of obligation, the value of the secured property should be decided at the time of ownership transfer by an independent party under the court supervision.

\footnotetext{
${ }^{17}$ See Article 2348, Article 2365 and Article 2459 French Civil Code

${ }^{18}$ See Article 2372-3 French Civil Code

${ }^{19}$ See Art L,143-3 French Commerce Code

${ }^{20}$ See Article 2459 French Civil Code
} 
In case there is no agreement on the method of foreclosure, both French and Vietnamese legislation allow the public auction of the collateral ${ }^{21}$. There again rises some other concerns as well.

\section{Concern 4: How to seize/ repossess the se- cured property for foreclosure}

One of the most burdensome issue in secured property foreclosure for secured obligation performance is how to repossess the secured property. It is simple if the property is under the possession of the creditor. However, if the creditor does not have possession over the asset ${ }^{22}$ and the debtor or the person who is holding the asset does not voluntarily give the secured asset over the hand of the secured party or the third party for foreclosure, it is really a nuisance in Vietnam. Although Article 301, Vietnamese Civil Code 2015 sets forth that "if the person holding the collateral fails to turn over the collateral, the secured party has the right to bring a claim to court, unless otherwise provided by relevant statutes" and Point 5, Article 323 of the same code regulates that the mortgagee is entitled to "demand the mortgagor or a third party holding the mortaged property to turn it over to the mortgagee for foreclosure".

Additionally, Point 1, Article 7, Resolution No. 42/2017/QH14 on pilot settlement of bad debts of credit institutions and the latest draft Decree of Government on security transaction suggests that the secured party is entitled to seize secured property if the securing party or a third party who is holding the secured party does not turn the property over. The secured party can also request the support from local authority and local police to maintain public order and facilitate the repossession ${ }^{23}$. However, local authority and local police, in reality, do not play the main role in repossession process but only do the fuction of supporting to some extents. Vietnamese law just states that the secure party is entitled to demand the turning over the secured party and once people with obligations refuse to, it can seize the secured property for foreclosure. However, once the debtor tries to prevent the creditor from reposseing the secured property, the secured party has no right to unilaterally repossess the secured property without violating the public order. Without a voluntary

\footnotetext{
${ }^{21}$ See Point 2, Article 303 Vietnamese Civil Code 2015 and Article R322-1 and Article R322-5 French Civil Enforcement Proceedings Code

${ }^{22}$ Mortgage in Vietnam and non-possessory pledge in France

${ }^{23}$ See Point 5, Article 63, Decree 163/2006/NĐ-CP and latest draft Decree
}

consent and cooperation of the debtor, it is quite difficult for the creditor to repossess or seize the property in a peaceful way and still keep the public order. Extra-judicial method to quickly repossess collateral and collect debt with the use of "unofficial forces" is currently unlawful and unregulated. In spite of a high success rate of $80-90 \%{ }^{24}$, such application of unlawful method may bring creditors with legistimate rights to negative social media attention and unwanted publicity, resulting in the negative impact on their reputation. As a result, the secured party seems to have only one choice which is bringing a lawsuit and waiting for a judgement so that they can have the support of the judgement enforcement agency. However, the judicial process is most of the time lengthy when " foreclosure through the court system may take two years, assuming that the judgement enforcement and sale of the collateral go smoothly" 25 .

In addition, subject to Point 2, Article 7, Resolution No. 42/2017/QH14 on pilot settlement of bad debts of credit institutions, in order to seize the secured property, in the security agreement, there must present a clause regulating that the securing party accepts the seizure of secured property of bad debts by credit institution, branch of foreign banks in accordance with the law ${ }^{26}$. Likewise, the security transaction or security devices must be registered according to law ${ }^{27}$. However, in reality, "nearly $100 \%$ of security agreements that fall under the case of bad debts do not contain any clauses mentioning about seizing right" and a great number of pledge and mortgage transactions that are not required to register by the law will not offer the creditor any rights of seizure ${ }^{28}$. Consequently, although the law provides for the right of seizure, in practice, it is quite hard to do so.

Concerning the foreclosure of property in case of bad debts under judicial judgement, managers of some commercial banks state a fact that "after a court ruling about the seizure of secured property to foreclose, the law enforcement agency is in the process of organizing auction then, the court receives a lawsuit from

\footnotetext{
${ }^{24}$ See Xuan-Thao Nguyen and Bich Thao Nguyen. Transplanting Secured Transaction Law: Trapped in the Civil Code for Emerging Economy Countries. Robert H. McKinney School of Law. Legal Studies. Research Paper No. 2014-39, p46

${ }^{25}$ See Xuan-Thao Nguyen and Bich Thao Nguyen. Transplanting Secured Transaction Law: Trapped in the Civil Code for Emerging Economy Countries. Robert H. McKinney School of Law. Legal Studies Research Paper. No. 2014-39, p46

${ }^{26}$ See Point 2, Article 7, Resolution No. 42/2017/QH14 on pilot settlement of bad debts of credit institutions

${ }^{27}$ See Point 2, Article 7, Resolution No. 42/2017/QH14 on pilot settlement of bad debts of credit institutions

${ }^{28}$ See Trương Thanh Đức. Luẩn quẩn quyền thu giữ tài sản bảo đảm. Báo Mới. $2^{\text {nd }}$ October 2017. Available from https://baomoi.co m/luan-quan-quyen-thu-giu-tai-san-bao-dam/c/23433723.epi;
} 
a third party claiming a dispute relating to such property. As a result, enforcement body has to stop the sale of property and waits for the dispute settlement over the property, prolonging the secured property foreclosure some more years.

In fact, the secured property can only be seized if it is not a property in dispute ${ }^{29}$. According to Net Le (2017), the mortgagor can prevent the mortgagee's seizure of collateral. The mortgagor can accomplish that simply by engaging in actions which put the collateral in dispute within fifteen days of the publication of information regarding the seizure. Another problem under Resolution 42, conditions for seizing collateral is that only credit institutions, organizations and companies that trade and handle bad debts are allowed to seize the collateral, while others (such as debt collection services) receive no such authorization, and only to the extent that the seizure does not violate legal prohibition.

Furthermore, another extremely noticeable concern is the case when the property is under the possesion of a third party who has the right of property retention to secure for an obligation that has not been performed by the obligor (under a bilateral contract) ${ }^{30}$. Because the retention of property will be terminated once the person who is retaining property loses actual possession of the property ${ }^{31}$, the person retaining the property will be very reluctant to turn over the property that he/she is possessing or else his privilege of retaintion will no longer exist. As a result, it is much unlikely that he/she will turn it over for his/ her own sake and Vietnamese law still leaves this concern unsolved. French laws, in contrast, have relatively clear provisions about secured property foreclosure. Before judicial judgement, as presented hereinabove, in the equitable procedure, the active involvement of debtor in the enforcement is helpful, more effective and can avoid conflicts and complications.

In case the judicial intervention is necessary, the beneficiary of a mortgage or pledge may apply to the court for an order to seize the property to be served on the debtor by a bailiff (huissier). The property is sold by way of a public auction at a hearing before a civil court $^{32}$. However, in principle, a debtor in good faith can always ask the court for a grace period (delai de grace) or "reasonable delay of payment"33. With regard to the enforcement of immovable property, the

\footnotetext{
${ }^{29}$ See Point d, 2 Article 7, Resolution No. 42/2017/QH14 on pilot settlement of bad debts of credit institutions

${ }^{30}$ See Article 346, Article 347 Vietnamese Civil Code 2015

${ }^{31}$ See Point 1, Article 350 Vietnamese Civil Code 2015

${ }^{32}$ See French Civil Enforcement Proceedings Code, L.311-1 onwards, and R.311.1 onwards

${ }^{33}$ See Art 1244 French Civil Code
}

debtor is protected by notice requirements at different stages of the proceedings with minimum time periods between these stages and there are some regulations if the eviction is required. If the security rights are on immovables, especially when the encumbered property is the main residence of the debtor or if it is in the winter period (from November 1st to March $15^{\text {th }}$ ) no eviction from private property may take place as a humanitarian measure, to ensure that people do not end up homeless in the coldest part of the year ${ }^{34}$. Obviously, a sale can always be postponed or even avoided by the payment of the debtor or by an agreement between the parties allowing the debtor to pay in instalments. Concerning movable property, the possibility for a court to grant grace periods is generally limited to non-commercial debtors.

If the seizure of the property can not be avoided, a court order to seize property will be served on the debtor by a bailiff and only the bailiff appointed by the court can conduct the enforcement (exécution forcée) by seizing the property and preserving or maintaining it until the public auction ${ }^{35}$. However, before seizing, the bailiff will serve a notice to the party with obligation or the person who is taking possession of the property $^{36}$. The bailiff will invite the third party who is holding the property to the court and ask him/ her to nominate the kind of property under the ownership of the debtor that he/she is holding. The seizure can only be carried out after 8 days from the date of the court's order requesting the payment served on the debtor $^{37}$. Furthermore, the seizure will be done wherever the secured property is found no matter whether it is under the possession of the securing party or of any third party ${ }^{38}$. The third party who is taking possession of the property has to turn over the property to the bailiff and brings a claim to the court to request damages if he/she has rights to the property seized ${ }^{39}$. Any third parties refuse to turn over the secured property for foreclosure or gives false information about the property of the securing party that he/she is holding will be liable to pay fine or damages (if there is any $)^{40}$. It is again noticed that if the property is the

\footnotetext{
${ }^{34}$ See The Connexion. Winter eviction ban. $1^{s t}$ November 2014 Available from https://www.connexionfrance.com/Archive/Winterevictions-ban-until-April-1

${ }^{35}$ See Paragraph 1- Article 122-1 French Civil Enforcement Proceedings Code

${ }^{36}$ See Article R221-11 and R321-1 to R321-5 French Civil Enforcement Proceedings Code

${ }^{37}$ See Article R221-10 French Civil Enforcement Proceedings Code

${ }^{38}$ See Artcile R221-9 French Civil Enforcement Proceedings Code

${ }^{39}$ See Article R.221-21 and Article R.123-1 French Civil Enforcement Proceedings Code

${ }^{40}$ See Article R.221-21 and Article R.123-1 French Civil Enforcement Proceedings Code
} 
main residence of the securing party, eviction process is not allowed in some circumstances ${ }^{41}$ and some kinds of property such as the movables that are essential for the life and work of the securing party and his/her family or essential tools to take care of the disabled or the people in sickness ${ }^{42}$ cannot be seized. In practice, only when the rights of creditors are well protected, they would be more willing to enter into security transactions and give loans, which will foster the economic development. Obviouly, the rights of disadvantageous people should also be considered. Therefore, the law should regulate so that the need of protecting creditors's legitimate rights and the desire of supporting the disadvantageous parties are balanced. The suggestion is that except for the some humantarian reasons such as when the property is the main residence of the securing party or the seizure of the secured property will affect seriously the rights of children and the disabled and the like, law should explicitly and clearly offer the secured party a right to effectively seize or repossess the property with a more active and decisive role of the court without the need of a court ruling (which may be lengthy and result in the capital tie-up) or offer the secured creditor an extra-judicial lawful method for peaceful foreclosure, retaining the good image and reputation of credit institutions in the market.

\section{Concern 5: Fruit and incomes derived from the pledged property}

Vietnamese law sets forth that fruits and incomes derived from the pledged property shall be returned to the pledgor when the pledge is terminated in the circumstances when the obligation terminates or when the pledge is cancelled or substituted by another security devices ${ }^{43}$. However, whether the fruits and incomes derived from the pledge property during the period of pledge or when the pledged asset is foreclosed should be returned to the pledgor or should be substracted from the loan has not been regulated.

French Civil Code provides that if the pledgee is allowed to use the pledged property, such as in case of immovable pledge (amtichréses), fruits and incomes derived will be accumulated and the sum will be subtracted from the interest and if it is more than the interest, the sum will be subtracted from the original

\footnotetext{
${ }^{41}$ See The Connexion, $1^{\text {st }}$ November 2014, Retrieved form https:/ /www.connexionfrance.com/Archive/Winter-evictions-ban-until-A pril-1

${ }^{42}$ See Point 5 and Point 7 Article L.112-2 French Civil Enforcement Proceedings Code

${ }^{43}$ See Point 1 and Point 2 Article 315 and Article 316 Vietnamese Civil Code 2015
}

$\operatorname{loan}^{44}$.

Because the nature of pledge is the delivery of property owned by the pledgor to the pledgee ${ }^{45}$, the property is under the possession of the creditors for a relatively long period of time until the performance of obligations. During such time, taking the example that the secured asset is a number of apartments for rent, if the secured party does not have effective methods to exploit the use of property for incomes or carelessly manage the asset and results in a loss in incomes, the securing party will suffer substantially. Currently, both Vietnamese and French law does not have provisions to force or encourage the pledgee to exploit the pledged sasset in a diligent manner to benefit both parties. It is suggested that law should provide that in case of possessory pledge, the pledgee is obliged to effectively and diligently manage and exploit the secured property and that the interest and original loan will deduct the incomes and fruit derived.

\section{CONCLUSIONS}

With the purpose of helping individuals and businesses to gain access to credit and increase the credit availability of credit for them, it is necessary that Vietnamese laws on secured transactions be better developed so that they embrace not only the quintessence of French law but also international best practices. The suggestions include the appearance of provisions regulatings a more active role of the securing party in serurity right enforcement process under judicial supervion, the court's involvement in property value appraisal in case of collateral substitution for debtor's obligation performance, an extra-judicial mechanism for creditors for collaterall repossession and finally a provision setting forth an obligation of the secured party to diligently and effectively exploit the secured property to earn maximum fruit and incomes and deduct such amount from the interest and original loan.

\section{COMPETING INTERESTS}

The author declare that she has no conflicts of interest.

\section{AUTHORS' CONTRIBUTIONS}

Le Bich Thuy has done all works of the article as a sole author.

\footnotetext{
${ }^{44}$ See Paragraph 2- Article 2085 French Civil Code and Nguyễn Ngọc Điện. Một số suy nghĩ về đảm bảo thực hiện nghĩa vụ trong luật dân sự Việt Nam. Trẻ Publishing House. 1998

${ }^{45}$ See Article 309 Vietnamese Civil Code 2015
} 


\title{
Xử lý tài sản đảm bảo theo các quy định của pháp luật nước Pháp và của pháp luật nước Việt Nam
}

\author{
Lê Bích Thủy*
}

Trường Đại học Kinh tế - Luật, ĐHQG-HCM

Liên hệ

LÊ BíCH THỦY, Trường Đại học Kinh tế -

Luật, ĐHQG-HCM

Email: thuylb@uel.edu.vn

Lịch sử

- Ngày nhận: 10-2-2019

- Ngày chấp nhận: 11-3-2019

- Ngày đăng: 26-6-2019

DOI :

https://doi.org/10.32508/stdjelm.v3i2.548

\section{Check for updates}

\section{Bản quyền}

๑ ĐHQG Tp.HCM. Đây là bài báo công bố mở được phát hành theo các điều khoản của the Creative Commons Attribution 4.0

International license.

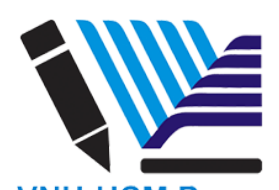

VNU-HCM Press

\section{TÓM TẮT}

Tại Việt Nam, do năng lực tài chính hạn chế, các doanh nghiệp vừa và nhỏ thường phải vay từ các tổ chức tín dụng, hâuu hết là qua các hợp đồng thế chấp và cầm cố. Do đó, để có thể thúc đẩy phát triển kinh tế, điều quan trọng là các cá nhân và doanh nghiệp cần được hộ trợ tiếp cận với các nguồn vốn vay. Để khuyến khích được các nguồn vốn vay, các quy định pháp luật về các biện pháp xử lý các tài sản đảm bảo cân rất rõ ràng và hiệu quả để bên cho vay có thể dự đoán được thời gian và các chi phí liên quan đến việc thu hồi các khoản nợ có đảm bảo. Trên thực tế, các quy định của pháp luật Việt Nam về giao dịch bảo đảm gần đây đã được hoàn thiện hơn với sự ra đời của Bộ luật dân sự 2015. Bộ luật đã bổ sung thêm hai biện pháp đảm bảo là bảo lưu quyền sở hữu và cầm giữ tài sản. Bộ luật cũng cho thấy rõ ràng tính chất đối vật và đối nhân của các biện pháp bảo đảm cũng như hoàn thiện cơ chế hiệu lực đối kháng với bền thứ ba. Bài viết trình bày một số khác biệt giữa các biện pháp xử lý tài sản đảm đối với hình thức thế chấp và cầm cố theo các quy định pháp luật của Pháp và của Việt Nam; đông thời, đề xuất sửa đổi các quy định pháp luật Việt Nam có liên quan nhằm bảo vệ tốt hơn quyền lợi của cả bên bảo đảm lẫn bên nhận bảo đảm trong hình thức thế chấp và cầm cố thông qua rút kinh nghiệm từ thực tiễn tại Pháp. Các đề xuất bao gồm: bên bảo đảm cần được đóng một vai trò tích cực hơn trong quá trình xử lý tài sản đảm bảo dưới sự giám sát của cơ quan tư pháp, toà án cần can thiệp vào quá trình định giá tài sản bảo đảm, cần có cơ chế để bên nhận bảo đảm được thu hồi tài sản bảo đảm mà không cần toà án can thiệp, cần quy định nghĩa vụ của bên nhận bảo đảm đối với việc khai thác tài sản bảo đảm một cách hợp lý để thu được hoa lợi và lợi tức tối đa và trừ số tiền tương ứng với giá trị của hoa lợi, lợi tức ấy khỏi khoản vay ban đầu và lãi vay phát sinh.

Từ khoá: tài sản đảm bảo, biện pháp xử lý, thực thi quyền được đảm bảo, bảo lưu quyền sở hữu 